Katarzyna Smyczek

Uniwersytet Łódzki

\title{
Estradowy przechera, ludowy trickster O satyrach Mariana Załuckiego
}

\section{Strategia artystyczna}

Partia stanęła na czele przemian, za partią stanął naród. Dokonała się sprawiedliwość dziejowa. Pięść socjalizmu zmiażdżyła przegniłe twory imperialnej kultury, której truchło stało się płodną mierzwą rewolucji. Nowa, pozbawiona treści burżuazyjnych sztuka niosła proste marksistowsko-leninowsko-stalinowskie przesłanie. By uniknąć błędów i wypaczeń poprzedniego systemu, artyści zobowiązali się nie wpadać w szał twórczy, a także bezwzględnie stosować nowe wytyczne dotyczące wyrobu dzieł sztuki. Do wykonywania zawodu wolnego (typ: pisarz/poeta) uprawniała przynależność do związku literatów. W pisarskim kołchozie mogli znaleźć się tylko ci, którym dane było zanurzyć się w bezbrzeżnej rzece mądrości socjalizmu. Zdawałoby się, że w ówczesnej rzeczywistości niemożliwa była żadna swoboda twórcza.

Marian Załucki swój pierwszy tomik poetycki wydał w 1954 na oficjalnym, kontrolowanym przez władzę rynku literackim. Jako artysta estradowy zadebiutował w krakowskim teatrze satyryków już kilka lat wcześniej. Kłopotliwy mecenat partii robotniczej nie przeszkadzał jednak artyście w uprawianiu twórczości niezaangażowanej. Niezaangażowanej w nic. Załucki nie składał heksametrów na cześć traktorzystów. Zamachy na społeczną własność socjalistyczną nie budziły w poecie gniewu. Ryszard Marek Groński w Puszce z Pandora wspomina:

Młody autor stronił od problematyki pierwszoplanowej. Lepiej czuł się w kręgu rodzinnym, wśród normalnych spraw normalnych ludzi. 
Niestety, miłość, zakochanie, zdrady, randki - zaliczono do reliktów drobnomieszczańskich. Fraszki i wierszyki na te odwieczne tematy lądowały w koszu. Od czego jednak unik? Satyryk z marginesów tłumaczył srogim redaktorom, że utwory, jakie przynosi, to nie są utwory oryginalne, lecz tłumaczenie z rosyjskiego. Radziecki satyryk Suchochwostow czy Kokoszajski pisze o uczuciach i prywatności człowieczej. On to tylko tłumaczy na polski; obcowanie z przodującą radziecką satyrą szalenie go inspiruje i pogłębia. W rocznikach krakowskich gazet wiele wierszyków opublikowanych na obowiązkowych kolumnach humoru i satyry - to mistyfikacje. Owi radzieccy autorzy nigdy nie istnieli. Przekłady są oryginałami ${ }^{1}$.

Z drugiej strony: choć pewne rachunki krzywd w ojczyźnie wciąż pozostawały nierozliczone, Załucki nie zdecydował się na otwarty sprzeciw wobec nowej władzy. Autor stronił od problematyki politycznej. Zarówno na scenie, jak i w wierszach wykreował postać zagubionego, odrobinę nieśmiałego, niezdarnego człowieka, zwykłego obywatela, jednego z wielu. Lichawy, pozbawiony siły fizycznej sceptyk był niemal bezradny wobec absurdów rzeczywistości. Jego jedyną bronią było ostrze satyry. Używał go jednak tak, by nie pozostawić po cięciach żadnych śladów. Bowiem tam, gdzie przebiega wyraźna granica między sacrum i profanum, artystyczną niezależność zapewnia zręczne lawirowanie między tym, co dozwolone, a tym, co zakazane. Poeta nie opowiada się po żadnej ze stron, ponieważ przynależność do jakiejkolwiek zbiorowości oznaczałaby wyrzeczenie się wolności własnej. Indywidualizm wyklucza kolektywizację.

Podmiot czynności twórczych u Załuckiego łączy w sobie cechy ambiwalentne: jest zarazem odważny i tchórzliwy. To kpiarz, który naigrywa się z samego siebie, lecz ironiczne sztychy nakierowuje również na nietykalne wówczas władze komunistyczne. By mówić o czymś zakazanym, naruszać sferę tabu, należy opanować sztukę zwodniczego posługiwania się słowami. Używać sztuczek, oszukiwać, grać. Pokuszę się zatem o stwierdzenie, że strategia artystyczna,

${ }^{1}$ R.M. Groński, Puszka z Pandora, http://zalucki.net/wspomnienia/6-o-poczatkach-jego-kariery (data dostępu: 2.05.2015). 
którą przyjął Marian Załucki, wpisuje się w archetyp strategii trickstera. Prometeusza, który przyniósł ludowi iskrę wesołości.

W mitologii trickster jest kimś, kto pośredniczy między światem ludzi i bogów², jak na przykład Hermes, który zsyłał śmiertelnikom marzenia senne oraz przekazywał im wolę mieszkańców Olimpu. W socjalistycznym kosmosie bóg-posłaniec materializuje się pod postacią instruktora kulturalno-oświatowego, czyli kaowca. Pełnił on funkcję przewodnika po zawiłościach, meandrach i pułapkach dawnej sztuki. Ponadto objaśniał obywatelom dyrektywy oraz postulaty ideowe zawarte w nowo powstałych tworach artystycznych.

Trzeba wiedzieć, że kaowiec $\mathrm{w}$ istocie miał w sobie coś z mitycznego herosa. Albowiem kaowiec niekiedy wiersze pisywał piękniejsze niż pryszczaci. Kiedy Kalina Jędrusik miała katar, gotów był nawet wbić się w suknię z głębokim dekoltem - słowem zapewniał rozrywkę na możliwie najwyższym poziomie. W państwie ludowym każdy obywatel powinien być szczęśliwy, każdy powinien się uśmiechać, a obowiązkiem władzy jest tego dopilnować. Kaowiec to człowiek, który w imię prawdy, w imię imperatywu szczęśliwości, w imię dalszej budowy socjalizmu, musiał urodzić się na kamieniu ${ }^{3}$. Życie jednego z tych przodowników ludowego oświecenia Marian Załucki sportretował w utworze pod tytułem Człowiek, który musiał być geniuszem.

Na zapadłej prowincji, gdzie - mimo powszechnie obowiązującej doktryny materializmu dialektycznego - „diabeł na dobranoc śwista”4, mieszkał Bogu ducha winny urzędnik. Z powołania księgowy, posłuchajmy, jak przeznaczenie uczyniło zeń męczennika ${ }^{5}$ :

${ }^{2}$ M. Zaleski, Zbigniew Herbert - stroiciel nieładu, <wyborcza.pl/1,75475, 17086890,Zbigniew_Herbert_stroiciel_nieladu.html> (data dostępu: 2.05.2015).

3 Zob. M. Załucki, Człowiek, który musiał być geniuszem, [w:] idem, Uszczypnij Muzo, Kraków 1955, s. 26-28. Utwór został opublikowany również w kolejnym tomiku M. Załuckiego pt. Oj-czyste kpiny.

${ }^{4}$ Ibidem, s. 26.

5 Według Tadeusza Peipera śmieszność to „nieszczęście, które wzbudza radość”. Już Sokrates zwrócił uwagę na to, że komizm jest swoistą mieszaniną tragedii i komedii. Zob. B. Dziemidok, O komizmie. Od Arystotelesa do dzisiaj, Gdańsk 2011. 
Przyszedł okólnik...

Dot.: kultury.

Żeby podnosić...

Patrzą: który?

(Inteligentów jest nas trzech)

Kulę się, kurczę...

Nadaremnie.

Zdolniejsi tamci dwaj ode mnie -

Więc padło na mnie.

Pech $^{6}$.

Przyznać trzeba, że Załucki dość przewrotnie realizuje model literatury wypracowany przez radzieckich towarzyszy pisarzy: jego utwór ma socjalistyczną formę i realistyczną treść. Człowiek, który był geniuszem przypomina pismo urzędowe. Forma ta jest najbliższa sercu osoby mówiącej - inteligenta działającego w aktywie. Język to matryca wszelkiego poznania. Świat księgowego kurczy się do rozmiarów biura rachunkowego, ponieważ by zilustrować swój dramat, sięga on po rekwizyty leksykalne właściwe stylowi kancelaryjnemu. Ta konsekwencja stylistyczna wzbudza kolektywny śmiech.

Podmiot liryczny nie desperuje. Mówi krótko (wręcz skrótowo) i węzłowato. Wykwalifikowany księgowy w każdej sytuacji potrafi zachować zimną krew. Nawet wtedy, kiedy stawia się przed nim zadania wykraczające poza jego kwalifikacje.

Kultura ma być wysoka (wydano wyraźne zalecenie: podnosić!). Okólnik jednak nie precyzuje, o jaką kulturę chodzi. Czy o kulturę rozumianą jako całokształt materialnego i duchowego rozwoju człowieka? Kulturę osobistą? Kulturę języka? Kulturę picia herbaty, kawy, mleka, wody, może alkoholu? Czy przeciwnie: o kulturę niepicia? Czy też wreszcie o kulturę agrarną - wszakże sam termin kultura pochodzi od łacińskiego wyrażenia cultus agri, czyli uprawa roli, i w tym właśnie znaczeniu najbliższy jest „generalnej linii” ideowej partii robotniczej.

${ }^{6}$ M. Załucki, op. cit., s. 26. 
Skrupulatny buchalter oszołomiony tak pogardzanym $\mathrm{w}$ jego zawodzie brakiem precyzji stara się podnieść wszystko, co w jego miejscu zamieszkania można uznać za przejaw jakiejś kultury. Każdemu ważnemu gminnemu wydarzeniu towarzyszą tzw. artystyczne części ${ }^{7}$. Odbywa się koncert za koncertem. Gdy baletnice padają ze zmęczenia, nasz księgowy dzielnie je zastępuje. Nie tylko tańczy i układa choreografie, pisze także ogólnie pojęte teksty i zdziera gardło na odczytach o cudach przyrodniczych tego świata. Z odwagą godną poskramiacza lwów reżyseruje Krety i inne sztuki. Owszem, jeśli trzeba, może zagrać Telimenę i jest w swoim damskim wcieleniu tak wiarygodny, że byłby w stanie uwieść samego siebie. Wskrzesza życie kulturalne prowincji, a także sam, artystycznie już rozgrzany, rozwija własne, nieznane mu do tej pory talenty. Kto wie, może przechera z „diablego wyświstowa” oprócz ksiąg rachunkowych pozostawi po sobie coś na miarę „Odprawy posłów radzieckich":

\section{Wierszyk ułożyć?}

Dobra - leci!

(Umiem bez rymu. Jak poeci)

Nawet z biedą

Mógłbym łabędziem być i Ledą

Znamienna dla podmiotu lirycznego jest tricksterska niedbałość o sacrum kultury ${ }^{9}$. Z pogardą i lekceważeniem mówi o sztuce współczesnej. By napisać wiersz, wystarczy według niego wystrzegać się rymów. Księgowy wykazuje się także nieznajomością rodzimej frazeologii. Poprawny zwrot brzmi: „od biedy”, nie „z biedą”.

Nieuważny czytelnik (np. delegat Głównego Urzędu Kontroli Prasy, Publikacji i Widowisk) może dojść do wniosku, że monolog

${ }^{7}$ Ibidem, s. 26.

8 Ibidem, s. 27.

${ }^{9}$ B. Stokłosa, Trikster - postać mityczna, archetyp i figura twórcy, „Opposite” 2011, nr 2, <http://opposite.uni.wroc.pl/2011/stoklosa.html> (data dostępu: 22.03.2015). 
pechowego księgowego świadczy o bezbrzeżnej ignorancji osoby mówiącej. Widzi gag rodem z farsy, w której głupiec przewraca się na wyrzuconej przez siebie skórce banana. Widzi, że na twarzy głupca pojawia się grymas. Nie widzi natomiast, że jest to grymas sardoniczny. Pod maską wioskowego błazna kryje się ironista, który, o ironio losu, padł ofiara sytuacji ironicznej ${ }^{10}$ stworzonej przez Załuckiego. Trickster to niepełnoprawny antagonista bóstwa naczelnego ${ }^{11}$. Gorszy brat pozytywnego herosa kulturowego, który przez swoje pozorne niedołęstwo bywa komiczny. Można zatem przypuszczać, że księgowy celowo popełnia błąd. Szelmowsko puszcza do czytelnika oko, wyśmiewając socjalistyczną propagandę sukcesu. Sugeruje, że jak mityczny Zeus uwiódł Ledę, podobnie bieda bez porozumienia z egzekutywą próbuje podstępnie posiąść tak dobrze zapowiadającego się członka aktywu. Co wykluje się z takiego związku? Księgowy w miłosnym akcie z ubóstwem - na kilometr cuchnie to zachodnim symbolizmem i dywersanctwem. „Zwodnicze posługiwanie się słowami” ${ }^{12}$ podmiot mówiący opanował w stopniu mistrzowskim. Jego hymn na cześć własną władze wzięły sobie mocno do serca. Do gminy dotarł kolejny okólnik. Tym razem od kolegi artysty wymaga się, by stworzył coś na miarę Hamleta, jednakże z zachowaniem rodzimych realiów:

\footnotetext{
Żeby kulturę znów do góry...

Mało im

Marzą o czymś innym

Kuszą mówią mi

„Kolego!

Hamleta na szczeblu gminnym!...

Czy coś takiego!...”13
}

${ }^{10}$ Zob. D. Muecke, Ironia: Podstawowe klasyfikacje, przeł. G. Cendrowska, [w:] Ironia, red. M. Głowiński, Gdańsk 2002, s. 46.

${ }^{11}$ B. Stokłosa, op. cit.

12 Zob. D. Muecke, op. cit., s. 46.

${ }^{13}$ M. Załucki, op. cit., s. 27. 
Tego rodzaju żądanie wymusza na naszym szachraju zmianę taktyki. Zdejmuje on maskę pyszałka, by wcielić się w rolę poczciwego skromnisia ${ }^{14}$. Tak jak Hamlet w rozmowie z Gildensternem i Rozenkrancem, udziela przyjaciołom z egzekutywy wymijających odpowiedzi: że nigdy nie pisał dramatu, że takie rzeczy to raczej na szczeblu państwowym lub chociaż powiatowym. Księgowy stał się ofiarą konfliktu tragicznego. Hamlet to sztuka dość problematyczna - trudno stworzyć adaptację, która nie byłaby aluzją do wciąż w owym czasie niestabilnej sytuacji politycznej. Gminna Antygona ryzykuje nie tylko stanowiskiem. Ma też najprawdopodobniej wątpliwości natury estetycznej - jak uczynić tę sztukę atrakcyjną dla miejscowego kolektywu? Zaprezentować rozterki na poły szalonego syna sołtysa? Czy też raczej uczynić z Hamleta pożytecznego idiotę, kapitalistę, który sam się unicestwi i umierając, na swojego tymczasowego następcę naznaczy Józefa Stalina, pod którego protektoratem wieśniacy założą pierwszą w dziejach ludową radę gminy?

Ironista - człowiek poczciwy - nie godzi się na zbrodnię, której partia każe mu dokonać na światowej klasyce dramatu. Niestety w tamtych okolicznościach nie było miejsca na sumienie i wątpliwości. Trzeba było czynów. Trzeba było geniuszy:

\author{
Nie dali dojść do słowa \\ Aktyw i Rada Narodowa: \\ „Że się ostatni geniusz zrodził \\ Kiedyś tam jeszcze w Nowogródku?! \\ To - mówią - co? \\ To nic. Nie szkodzi. \\ Trzeba się rodzić, \\ Trzeba się rodzić, \\ Trzeba się rodzić \\ Aż do skutku”15
}

${ }^{14}$ Od Arystotelesa ironia (gr. eironea) znaczyła tyle, co „udawana skromność”. Ten rodzaj ironii, zwany „naiwną” (Muecke, Worcester), wymaga od ironisty ukrycia się za postawą osoby skromnej, „naiwnego głuptasa”, prostaczka. Zob. D. Muecke, op. cit., s. 46-74.

15 M. Załucki, op. cit., s. 28. 
a kto „prośby” nie posłucha, temu, w imię Ojca, Syna i Lenina, pański krzyż!

Oświecony promiennemi blaski „nowej myśli” wyklęty lud ziemi zaczął korzystać z przywilejów zarezerwowanych dotychczas jedynie dla wybranej grupy społecznej. Na gwałt trzeba było ukształtować w obywatelach wrażliwość estetyczną. Warunki były ciężkie. Brakowało intelektualnych elit, zwłaszcza na prowincji. Władza dysponowała tym, co zostało. Spośród trójki inteligentów na stanowisko animatora życia kulturalnego gminy naznaczyła właśnie księgowego (komuż bliżej do ksiąg). Księgowy miał pewność, że wybór ten nie do końca był przemyślany. Zdarzenie skwitował ironicznym stwierdzeniem „moje nieszczęście: kultura”16.

Prawdopodobnie zdawał sobie sprawę z tego, że lokalni proletariusze nie mieli aż tak wysokich aspiracji intelektualnych. Jedyna rzecz związana z kulturą, jaka podniesie się w okolicy, to poziom uczestnictwa ludności w ,artystycznych częściach”, ponieważ państwo było na tyle opiekuńcze, że gwarantowało odpowiednią frekwencję.

Człowiek, który musiał być geniuszem to historia bohatera socrealistycznego à rebours. Księgowy dzięki partii, a właściwie z winy partii, osiąga awans społeczny. Zmusza się go, by został geniuszem, by wykształcił w sobie odpowiednie talenty. „Inżynier dusz ludzkich” Marian Załucki obnaża absurdy systemu. Kulturę tworzą ludzie z przypadku, zupełnie do tego nieprzygotowani. Obywatele zamiast otrzymać solidną edukację kulturalną, są świadkami niedorzecznej farsy - bo jak inaczej można nazwać inscenizację Pana Tadeusza, w której jedną z głównych postaci kobiecych odgrywa małomiasteczkowy księgowy.

Trickster to ważny kulturowy wentyl bezpieczeństwa ${ }^{17}$. Śmiech to wyłom w świecie sztywnych zasad. Lud, który pozbawiony został duchowości, otrzymuje od Trickstera twór quasi-duchowy:

\footnotetext{
16 Ibidem, s. 26.

17 B. Stokłosa, op. cit.
} 
śmiech. Śmiech leży na granicy duchowości oraz biologii. Łączy w sobie boskość i materię. Trickster kaowiec poprzez śmiech obnaża niedoskonałość władzy. Zaburza status quo: okazuje się, że dobro robotników nie jest nadrzędnym celem partii robotniczej. Zauważmy, że krytyka władzy ludowej ukryta jest pod maską autoironii. Buchalter naigrywa się z samego siebie w roli kaowca, który jest przecież częścią systemu. To jednak wytrąca oręż z ręki cenzora - nie można wszakże odmówić obywatelowi konstytucyjnego niemal prawa do samokrytyki. Poza tym niewidoczne szpile nie kłują tak bardzo.

\section{Strategia przetrwania}

Lata 50. lub 60. Stolica Polskiej Rzeczpospolitej Ludowej. Obywatele Marian Załucki i Karol Szpalski zostali wezwani do wydawnictwa w sprawie pewnego pierzastego dysydenta:

- Ten gołąbek to ma być gołąbek pokoju?

- No nie... To zwykły gołąbek.

- Ale tamten to także gołąbek. Piórka ma, łapki ma, dziobek ma.

I w tym dziobku trzyma gałązkę oliwną.

- Nasz nie trzyma.

- A to błąd. To trzeba będzie przerobić.

- Tłumaczymy przecież: to zwykły gołąbek.

- A niespokrewniony z tamtym? W ogóle nie?

- Zgoda, może być kuzynem tamtego.

- Widzicie - od razu mówiłam: gołąbek pokoju!

- Nie całkiem, ale skoro redakcji na tym zależy...

- Zależy. Pewnie, że zależy. Młodzi czytelnicy powinni dostawać

książki z wydźwiękiem. A gdzie tu wydźwięk?

- Gołąb... gołąb grucha. O, jakoś tak: gru gru...

- Grucha... I co dalej?

- No, lata. W naszej książeczce lata.

- Lata, powiadacie. A dlaczego on nie lata nad Moskwą?18

${ }^{18}$ R.M. Groński, op. cit. Autor wspomina: „Opiekujący się młodym człowiekiem (znacznie od niego obrotniejszy) Karol Szpalski nakłania go do wspólnej pracy: piszą książeczki dla dzieci, wydawane w masowych nakładach. Oczywiście, 
Do 1989 roku w krajach Układu Warszawskiego należało przyjmować, że pokój przyniesiono ze Wschodu. Jeśli obywatele nie byli do tego faktu do końca przekonani, służebna była literatura, sankcjonująca ustalony przez władzę stan rzeczy. Przemyślana odpowiedź na pytanie dotyczące orientacji politycznej bajkowego gołąbka rozstrzygała o (nie tylko) twórczym byciu i niebyciu pisarzy.

PRL-owskie teatrum mundi wymuszało na ,aktorach” specyficzną technikę gry. Każdy, kto chciał bezpiecznie doczekać końca ostatniego aktu, musiał słuchać wskazówek dwóch różnych reżyserów równocześnie. Znaleźć równowagę pomiędzy tym, co mówi język propagandy, a tym, co podpowiada zdrowy rozsądek. Kiedy niemal wszystkie artykuły pierwszej potrzeby były towarem deficytowym, a materialistyczny raj na ziemi ciaggle pozostawał w sferze wyobraźni, rodacy przyjęli postawę trickstera (innymi słowy, by przeżyć, człowiek musiał „kombinować”). Sceniczna kreacja Załuckiego to nie tyle ,artystyczne kłamstwo”, co strategia przetrwania.

Bezmierna i nieodgadniona irracjonalność ówczesnej rzeczywistości zmuszała obywateli krajów demokracji ludowych do traktowania zasad logiki z przymrużeniem oka:

\author{
Wziąć tego, czego nie ma. \\ Dodać soli i kminku, \\ potem zmieszać z tym, czego \\ brak chwilowo na rynku. \\ Mieszać długo, dokładnie - \\ jak się znudzi, to przestać \\ i posypać tym, na co \\ absolutnie nas nie stać. \\ Można smażyć lub upiec, \\ lub przypalać na rożnach, \\ polewając tym, o czym \\ nawet marzyć nie można!
}

w bajkopisarstwie także musiały pojawić się «akcenty pozytywne». Jedną z książeczek autorzy poświęcili przygodom gołąbka. Sympatyczny wydał się im ten ptaszek”. 
Wszyscy u nas to jedzą -

dla każdego wystarczy,

na czym właśnie polega

polski cud gospodarczy ${ }^{19}$.

Utwory komiczne są specyficznym dokumentem czasów minionych $^{20}$. Konwencja przepisu kulinarnego, będącego parodią ówczesnych książek kucharskich, w których doradzano, jak z cebuli zrobić kotlet schabowy, przenosi nas w krąg skojarzeń gastronomicznych. W socjalistycznym świecie na opak marzenia, nawet te spożywcze, mogą być społecznie szkodliwe. Prosty człowiek jada proste potrawy - naród, który nie docenia gustu swojego lidera, wyzysk proletariuszy popiera. Za przykładem towarzysza Wiesława, Polak z definicji gardził egzotyką, natomiast nieprzyzwoitym wręcz afektem obdarzał kaszankę i flaczki. Władysław Gomułka przekonywał rodaków, że w kraju socjalistycznego dobrobytu nie istnieje potrzeba importowania żywności z Zachodu. Zwłaszcza jeśli obywatele „cierpią z powodu jej nadmiaru”, a władze zmuszone są wysyłać wszystko na Wschód do „bratnich” republik. Powszechnie wiadomo, że najwięcej witaminy ma polska kiszona kapusta, co często powtarzał także sam pierwszy sekretarz. Polacy zaś pytali go ironicznie i retorycznie o to, jak kwaszoną kapustę wycisnąć do herbaty ${ }^{21}$.

Rzeczywistość PRL-u przypominała świat przedstawiony literatury purnonsensownej. Dygnitarze partyjni stworzyli swoją własną wersję kosmosu²2, w której przyjmowało się na wiarę, że

19 M. Załucki, Przepis po polsku, [w:] idem, Kpiny i kpinki, red. L.J. Kern, Kraków 1985, s. 336. Wiersz ten, napisany w 1965 roku, zyskał dużą popularność 15 lat później podczas sierpniowych strajków na Wybrzeżu. Był kolportowany w biuletynach codziennych wydawanych przez „Solidarność” i przetłumaczono go na wiele języków. O ironio losu, los pechowca, który stał się sposobem na artystyczne życie, nie odstępował poety także pośmiertnie - Przepis po polsku drukowano jako utwór anonimowy.

${ }^{20}$ B. Dziemidok, op. cit., s. 163.

${ }^{21}$ Źródło informacji osobowe - moja babcia.

${ }^{22}$ G. Chesterton, Obrona absurdu, [w:] idem, Obrona świata, przeł. J. Rydzewska, Warszawa 2006, s. 26. 
musztarda i ocet to symbole luksusu. Gdzie niemożliwe stawało się możliwym: poranne zakupy trwały do wieczora, a klientów barów mlecznych paraliżował strach przed... gangami ortalionowymi. Ortalion z niedających się racjonalnie wyjaśnić powodów był materiałem tak wielce pożądanym, że obowiązkowe szatnie lokali gastronomicznych były często nawiedzane przez zorganizowane grupy przestępcze. Konsumenci, obawiający się o swe odzienie wierzchnie, nie mogli nic utrzymać w drżących z trwogi dłoniach, konsekwencją czego był niemiłosierny szczęk łańcuchów, do których przymocowane były łyżki oraz noże ${ }^{23}$.

Odczucie komizmu jest dostrzeżeniem zjawisk odbiegających od normy ${ }^{24}$. By sportretować jawnie niedorzeczne stany rzeczy, autor odwołuje się do poetyki purnonsensu ${ }^{25}$. (Jednak pamiętać należy, że zabieg ten jest tylko ironicznym chwytem, sposobem na ukazanie istniejącej w świecie realnym, acz absurdalnie zdeformowanej rzeczywistości). Poeta opisuje miejsce, gdzie możliwe jest spożywanie usmażonego „niczego”, polanego sosem z niedozwolonych - zapewne kontrrewolucyjnych - marzeń. Amorficzne byty przybierają konkretne postaci. Można je zjeść, upiec, mieszać, formować w dowolne kształty, jednocześnie zaprzeczając ich istnieniu.

Język propagandy posługiwał się stałym, niezmiennym, typowym dla siebie zestawem określeń, dzięki któremu przekłamywał rzeczywistość. Istotną jego cechą była również magiczność. Głoszone przez partyjnych tuzów formuły nie opisywały rzeczywistości, lecz miały charakter życzeniowy. O rzeczach pożądanych mówiono tak, jak gdyby istniały już w przestrzeni realnej. Nowomowa w pewien sposób kształtowała świat, który opisywała ${ }^{26}$.

Poeta szachraj bezlitośnie drwi z kreacjonistycznych predylekcji ludzi, bądź co bądź, o światopoglądzie materialistycznym.

${ }^{23}$ Patrz: przyp. nr 21.

${ }^{24}$ B. Dziemidok, op. cit., s. 20.

25 G. Chesterton, op. cit., s. 21-28.

${ }^{26}$ M. Głowiński, Nowomowa (Rekonesans), [w:] idem, Nowomowa i ciagi dalsze: Szkice dawne i nowe, Kraków 2009, s. 11-33. 
Załucki prześmiewczo naśladuje specyficzną retorykę mowy-trawy. Nadaje status bytu istniejącego czemuś, co nie istnieje. Do cudu gospodarczego à la polonaise potrzebne jest „coś” i „nic”absurdalność i komizm tego stwierdzenia uwydatniają się poprzez układ wiersza. Satyryk dzieli go na czterowersowe strofy z rymami w drugim i ostatnim wersie, dzięki czemu satyryczne kpiny mogą wybrzmieć z odpowiednią mocą. Pointą każdej ze zwrotek jest parafrastyczne określenie słowa „nic”, które w finale utworu zostaje w cudowny sposób rozmnożone.

Życie w irracjonalnie realnym państwie było niezwykle uciążliwe. Stanie w niekończących się kolejkach do pustych sklepów, brak perspektyw na lepszą posadę, czy choćby papieru toaletowego na wyposażeniu łazienki, doprowadziły do tego, że obywatele Polski Ludowej, by przetrwać, musieli stosować niezbyt uczciwe metody pozyskiwania rozmaitych korzyści. Człek musiał pozbyć się zatem moralnego kręgosłupa i w jego miejsce sprawić sobie „plecy”. Wiersz Kumoterstwa nie ma stanowi satyryczny komentarz Załuckiego na temat owej absurdalnej sytuacji:

Jest to właściwie tajemnica

Dość osobistej natury:

Miałem interes do księżyca...

By pełnią świecił z góry!

O to mi szło, ażeby jaśniej,

Bo gość był w pierwszej kwadrze właśnie...

- Dla pana - mówię - to drobnostka,

Kosmiczna błahostka,

A dla mnie - nie bez znaczenia!

Poetą wszak się - mówię - jest, nie?

Więc ma się - mówię - kilka westchnień

Pilnych do załatwienia!

Ponadto parę wzlotów duszy

Odwalić dziś koniecznie muszę...

I spotkać mam się pod kapliczką

$\mathrm{Z}$ pewną przystojną lunatyczką -

W związku z czym pełnię muszę mieć. 
Więc całą gębą -

Proszę -

Świeć! (...)

- Mnie się od pana,

Bądźmy szczerzy,

też - mówię - jakiś wzgląd należy!

Drukuję przecież w prasie

Recenzje z pańskiej działalności,

to znaczy wiersze o miłości,

O snach co to je ma się...

Ponadto drogi przyjacielu,

Wspólnych znajomków mamy wielu

Z lirycznych zwłaszcza kół...

Od lat są z panem za pan brat.

Niejeden nawet z pana spadł! (...)

Nie posłuchał.

Lecz kończę wiersz ten z myślą błogą,

Że jego morał dla nikogo

Nie jest już tajemnicą:

Wbrew temu co się ciągle mniema,

Widzicie - kumoterstwa nie ma!

(Na księżycu) ${ }^{27}$.

Poeta zabiega o względy księżyca, swego patrona, w sposób niezbyt poetycki. Pochlebia mu, bowiem ma doń ,interes” - potrzebuje inspiracji, by „odwalić” parę wierszy. Poprzez użycie oksymoronicznych („kosmiczna błahostka”) określeń stawia adresata swojej prośby na równi z bóstwem, lecz zaraz potem sprzeciwia się zasadom peanicznego dekorum i bezceremonialnie powołując się na swe rozliczne kontakty, stwierdza, że należy mu się jakaś pełnia.

Załucki doskonale gra utartymi schematami językowymi: apel podmiotu lirycznego może wydawać się bezcelowy, pamiętajmy jednak, że poeta - podobnie jak jego koledzy artyści - „z księżyca spadł”. Liryczna odezwa jest w gruncie rzeczy jak „wycie do księżyca” - czyli

${ }^{27}$ M. Załucki, Kumoterstwa nie ma, [w:] idem, Oj-czyste kpiny, op. cit., s. 29-30. 
czczy, próżny protest. Srebrzyste oko nocy, nie zważając na solidarność kręgów poetyckich, pozostaje nieczułe na braki aprowizacyjne (tutaj w postaci weny twórczej) i konsekwentnie świeci z profilu. Satyryk po raz kolejny sięga po parafrazę - ulubioną figurę retoryczną języka komunistycznej propagandy. $Z$ entuzjazmem godnym hożego komsomolca stwierdza, że kumoterstwa nie ma, po czym przewrotnie pointuje, że problem ten nie dotyczy księżyca. Twórczość satyryczna dostarczała wdzięcznego pola do popisu cenzurze, która nie tylko nie szczędziła zakazów drukowania lub rozprzestrzeniania takich utworów ${ }^{28}$. Co ciekawe, cenzorzy, tak surowi wobec gołąbka z dziecięcej bajki Załuckiego, pozostawali niefrasobliwi wobec jego poematów dla dorosłych. Satyra skierowana przeciwko władzy uderza w jej słabość, wydobywa wszystko to, co pod jakimś względem czyni ją jako przeciwnika gorszym, niższym niż się na pozór wydaje. Wrogość, która $z$ jakichś względów nie znalazła ujścia $w$ innej formie, może je znaleźć $w$ dowcipie. Śmiech jest szczególną bronią uciśnionych, wyzyskiwanych i prześladowanych ${ }^{29}$. Nawet słaby człowieczek Załuckiego uzbrojony w tricksterskie ostrze satyry może zwyciężyć w starciu z bardzo mocnym adwersarzem.

\section{Bibliografia}

Chesterton G., Obrona absurdu, [w:] idem, Obrona świata, przeł. J. Rydzewska, Warszawa 2006, s. 26.

Dziemidok B., O komizmie. Od Arystotelesa do dzisiaj, oprac. M. Bokiniec, Gdańsk 2011.

Głowiński M., Nowomowa (Rekonesans), [w:] idem, Nowomowa i ciagi dalsze: Szkice dawne i nowe, Kraków 2009, s. 11-33.

Groński R.M., Puszka z Pandora, http://zalucki.net/wspomnienia/6-o-poczatkach-jego-kariery (data dostępu: 2.05.2015).

Muecke D., Ironia: Podstawowe klasyfikacje, przeł. G. Cendrowska, [w:] Ironia, red. M. Głowiński, Gdańsk 2002, s. 43-74.

Stokłosa B., Trikster - postać mityczna, archetyp i figura twórcy, „Opposite” 2011, nr 2, http://opposite.uni.wroc.pl/2011/stoklosa.html (data dostępu: 22.03.2015).

${ }^{28}$ B. Dziemidok, op. cit., s. 203-204.

${ }^{29}$ Ibidem, s. 197-199. 
Zaleski M., Zbigniew Herbert - stroiciel nieładu, <wyborcza.pl/1,75475, 17086890,Zbigniew_Herbert_stroiciel_nieladu.html > (data dostępu: 22.03.2015). Załucki M., Człowiek, który musiał być geniuszem, [w:] idem, Uszczypnij Muzo, Kraków 1955, s. 26-28.

Załucki M., Kumoterstwa nie ma, [w:] idem, Oj-czyste kpiny, Warszawa 1959, s. 29-30.

Załucki M., Portret lizusa, [w:] idem, Oj-czyste kpiny, Warszawa 1959, s. 176-177. Załucki M., Przepis po polsku, [w:] idem, Kpiny i kpinki, red. L.J. Kern, Kraków 1985, s. 336. 